\title{
Development of Learning Materials through PBL with Karo Culture Context to Improve Students' Problem Solving Ability and Self-Efficacy
}

\author{
Siska Apulina Peranginangin ${ }^{1 *}$, Sahat Saragih ${ }^{1}$, Pargaulan Siagian ${ }^{1}$ \\ ${ }^{1}$ State University of Medan, INDONESIA \\ *CORRESPONDENCE: $\$ siskaapulinap@gmail.com
}

\begin{abstract}
The aim of this study was to analyze the effectiveness of learning materials through Problem Based Learning with Karo Culture Context (PBL-KCC), as well as improving students' mathematic problem solving ability and student self-efficacy. Learning materials developed were lesson plan, student book, student worksheet, mathematic problem solving ability test instrument and student selfefficacy questionnaire. This research is a development research using the development model of Thiagarajan 4-D model. Learning materials that have met valid criteria according to experts, were tested in class VII of SMP Negeri 2 Sibolangit. The results of the analysis of the data obtained indicate that learning materials based on PBL-KCC met the criteria of effectiveness and can improve mathematic problem solving ability and student self-efficacy. Based on the results of the study, it was suggested that mathematics teachers make an effort mathematic learning using learning materials based PBL-KCC.
\end{abstract}

Keywords: 4-D model, development of learning materials, PBL-KCC, mathematic problem solving ability, students' self-efficacy

\section{INTRODUCTION}

Education is a very important aspect for the life of a nation. Through education, the character and personality of each community is built. Educated people are expected to be able to compete with countries in the world that are full of competition. Future growth of the country will depend on knowledge. In this case, more jobs will be requirea higher education qualification (Dumciuviene, 2015).

Mathematics as a compulsory subject in formal education has a very important position and role. One of the objectives of mathematics is problem solving ability, that is important to be developed for students. This is also in accordance with the process standards of the National Council of Teachers of Mathematics said that mathematic problem solving skills are important abilities that need to be developed in mathematics learning (NCTM, 2010). Problem solving skills have an important place among the primary objectives of a contemporary curriculum (Ozturk \& Guven, 2016). A set of reasons for the importance of mathematical problem solving abilities, as follows: a) general cognitive skills problem solving develops, b) problem solving supports the development of creativity, c) problem solving is part of the mathematical application process, and d) problem solving motivates pupils to learn mathematics (Pehkonen, 2012).

This was obtained when the researchers conducted preliminary observations in class VII-B SMP Negeri 2 Sibolangit by giving a test question on mathematic problem solving abilities of students which was analyzed based on indicators of mathematic problem solving abilities. Indicators of solving mathematical problems

Article History: Received 8 January $2019 \bullet$ Revised 23 January $2019 \bullet$ Accepted 26 January 2019

(C) 2019 by the authors; licensee Modestum Ltd., UK. Open Access terms of the Creative Commons Attribution 4.0 International License (http://creativecommons.org/licenses/by/4.0/) apply. The license permits unrestricted use, distribution, and reproduction in any medium, on the condition that users give exact credit to the original author(s) and the source, provide a link to the Creative Commons license, and indicate if they made any changes. 
according to NCTM, are: (1) identifying elements that are known, asked, and the adequacy of the elements needed, (2) formulating problems or developing mathematical models, (3) applying strategies to solve problems, and (4) explain the results according to the problem. Furthermore, these indicators modified into three indicators and each indicator also consists of several aspects. The three indicators are: (1) understanding the problem thoroughly, (2) planning problem solving, and (3) choosing and implementing strategies to solve problems and evaluate (Charles et al., 1987).

However, students were reported that they have difficulties in mathematics problem solving (Tambychik, 2010). Even though mathematic is a very important subject in formal education and is closely related to human life, mathematics is not a subject of interest to students. The results of interview with teachers stated that word problem in mathematics was very difficult for students. It was also found that many students did not like mathematics because mathematics was too difficult for these students (Peranginangin et al., 2017). The results of interviews with teachers at the school stated that mathematics was a subject that was not in demand by most students. The results of the observations through the provision of diagnostic tests to students of class VII-A SMP Negeri 2 Sibolangit (7th grade students), with a test in the form of a description to describe students' ability to solve mathematic problems, obtain similar information; problem solving ability is very low.

From the student answer sheet on the problem solving test, the researcher interviewed three students. One student from each ability category. A low-ability student said that he did not understand the purpose of the problem. He claimed to forget the formula of looking for a square. From this it can be seen that students are not used to answering non-routine questions. Students tend to memorize formulas without understanding them. A student who is capable of saying that he has begun to be able to write down what is known in the problem. But after the researchers analyzed it, the students did not complete writing what they knew. There is still information that has not been written. Even though the information is important to answer the question. The student said that he had difficulty in determining what steps to do first. Then, for high-ability students, the student says that he understands well what is known and asked in the question. He understands the strategy of what he must do to answer the question correctly. in this case the researcher analyzes that it is fundamentally correct, but there is still a small negligence or a slight step error in copying, so that the score obtained is not maximal. From the results of the student's answers and the results of the interview, it can be concluded that students are still experiencing difficulties in solving problems, especially problems that are rarely encountered as in the problem above. Students' problem solving abilities are still relatively low.

Problem solving ability in mathematics needs to be trained and familiarized as early as possible with students (Gafur \& Sudia, 2015). This ability is needed by students as a provision in solving problems and problems found in everyday life. Besides problem solving skill, affective factors influencing mathematical problem solving performances (Furinghetti \& Morselli, 2009). Affective factors also have an influence on students' mathematical problem solving abilities. The ability to solve problems faced is expected to be able to generate motivation for students to find solutions to existing problems to try to solve them. Solutions obtained in solving problems faced, will spur students to find other solutions to the problems they face. This, if always accustomed, is expected to foster a positive attitude. Such attitudes include the confidence of students in their ability to do tasks, solve problems, and follow good learning activities to achieve desired goals also need to be improved, namely self-efficacy.

But from the results of interviews of researchers with mathematics teachers at SMP Negeri 2 Sibolangit regarding students' self-efficacy towards mathematics learning showed students were less challenged to solve difficult problems, students tended to give up and were lazy to solve non-routine mathematical problems. In addition, students tend to be anxious and afraid when the teacher tells students to present the answers to the front of the class. This makes students tend to be passive and afraid of being wrong to try to solve mathematical problems. This shows that student self-efficacy is low and needs improvement, because good self-efficacy will provide good motivation to learn.

Addressing the problems that occur in the field, namely in the process of learning mathematics in schools, especially related to mathematic problem solving skills and self-efficacy, teachers must make efforts to improve these conditions. Efforts made include improving the quality through the learning process, in this case the teacher chooses to use the PBM model. In addition to choosing a learning model, to improve quality, in this case the quality of mathematics education, must be accompanied by research, especially development research (Arikunto, 2010). Development that can be done is the development of learning materials.

The importance of learning materials in learning activities so that development is a very demanded thing for teachers. The students taught with instructional materials have excellent achievement scores compared to 
those taught without any material (Olayinka, 2016). The importance of developing learning devices is based on several reasons, among others, the availability of materials according to the demands of the curriculum, target characteristics, and demands for problem solving learning (Fitriani, 2014).

SMP Negeri 2 Sibolangit is one of the Junior High Schools in Deli Serdang Regency, which is directly adjacent to Karo Regency, North Sumatra. Most of the students in this junior high school are Karo with local culture (Karo Culture). Mathematics teachers should pay attention to the context of Karo culture in teaching students, including in choosing and using learning tools. The cultural context, through several studies, shows that it is beneficial for students, even plays a role in improving students' mathematic abilities.

The success of integrating cultural values into mathematics learning can be seen from the results of previous studies. Using familiar objects and contexts to teach mathematics can facilitate learning (D'Entremont, 2015). For this reason alone, it is important to link the cultural reality of the students to the learning of mathematics. The student-centered learning based on local culture model and the instrument for higher order mathematical thinking ability are valid and effective to use in teaching mathematics for junior high school (Saragih et al., 2017). Likewise, mathematics learning materials developed based on problembased learning models in the context of Karo culture are expected to be able to improve students' mathematic problem solving ability and student self-efficacy. Based on the description above, studies that focus on developing learning tools are important to do.

\section{REVIEW OF LITERATURE}

\section{Mathematic Problem and Mathematic Problem Solving Ability}

First The problem is a creation, in which an individual who faces felt the need to solve or want to solve (Aydogdu, 2014). Problem solving has generally been accepted as a means for advancing thinking skills. NCTM (2000) stated, "Solving problems is not only a goal of learning mathematics but also a major means of doing so. ... In everyday life and in the workplace, being a good problem solver can lead to great advantages. ... Problem solving is an integral part of all mathematics learning”.

Mathematic problem solving as the process of interpreting a situation mathematically, the which usually involves several iterative cycles of expressing, testing, and revising mathematical interpretation and of sorting out, integrating, modifying, revising or refining clusters of mathematical concepts from various topics within and beyond mathematics (Lesh \& Zawojewski, 2013). In the discipline of mathematics, the use of problem solving skills has been extremely important and highly influential (Vettleson, 2010). Problem solving is the foundation of all mathematical and scientific discoveries. In the disciplines of mathematics using problem solving skills have a very important influence. Problem solving is the foundation of all mathematics and the process of discovering new knowledge.

\section{Self-Efficacy}

Self-efficacy, beliefs about one's ability to accomplish specific tasks, influences the tasks employees choose to learn and the goals they set for themselves (Lunenburg, 2011). Self-efficacy also affects employees' level of effort and persistence when learning difficult tasks. Indicators of self-efficacy according to Bandura are: (1) beliefs to be able to solve various problems; (2) beliefs to be able to solve problems related to others; (3) the ability to solve problems with the right solution (Manurung, 2015).

Social cognitive theory, self-efficacy is very useful in creating confidence in a person (Sartawi, 2012). Selfefficacy affects the motivation of each individual, what efforts are made to foster a sense of confidence and the extent to which they can be confident in carrying out a task. In fact, self-efficacy has also been shown to influence someone to be able to conceptualize and respect one another.

From some of the above meanings, it can be concluded that self-efficacy is an individual's belief in dealing with and resolving problems faced in various situations and is able to determine actions in completing certain tasks or problems, so that the individual is able to overcome obstacles and achieve expected goals.

\section{Problem Based Learning with Karo Culture Context (PBL-KCC)}

Montago and Dawson said that culture is a way of life that is a certain way of life that radiates a certain identity from a nation (Daryanto, 2015). In this study, the cultural context used was Karo culture, because the setting of research was in high school in the Karo culture environment. The integration of the local culture with the PBL model forms a learning model which is referred to as Problem Based Learning With Karo Culture 
Context (PBL-KCC). PBL in one of student centered learning model. Teachers currently apply learning methods that are mode student center (Sapta et al., 2018). PBL-KCC based on learning theory that adheres to constructivist ideas and gives attention to the mathematical characteristics and utilization of aspects of Karo culture. This means that the design of the PBL-KCC model is a result of modification or refinement of the PBM model by paying attention to mathematical characteristics, the purpose of mathematics learning, and the utilization of cultural aspects (Karo culture) that greatly affect mental activity and development.

For the implementation of the culture, the syntax or PBL steps are modified in such a way as to incorporate elements of Karo culture that refer to the five main steps of problem-based learning, namely PBL-KCC is a learning model that refers to 5 (five) the main steps of problem-based learning, i.e: (1) the orientation of students to the problem, where the problem is given is a contextual problem that relates to the various contexts of Karo culture; (2) organizing students for learning; (3) guiding individual and group investigations; (4) develop and present the work; and (5) analyze and evaluate the problem solving process.

\section{Learning Materials}

Development is a process, a way, an action develop. Learning devices are a set of learning resources that allow students and teachers to carry out learning activities. Ibrahim said that learning materials are materials used in the teaching-learning process. Learning materials function to provide direction for the implementation of learning so that it becomes directed and efficient (Trianto, 2013).

Learning materials are a number of tools, media, instructions, and guidelines that students and teachers will use in the learning process. So the development of learning materials is a process carried out to produce a series of learning materials used by teachers and students in the learning process in the classroom. A series of learning tools that must be prepared by a teacher in the face of classroom learning, including: (a) Learning Implementation Plans; (b) Student Books; (c) Teacher Handbook (BPG); (d) Student Activity Sheet (LAS); (e) Test of learning ability. In this study, the learning tools developed were Student Books, Student Activity Sheets, Mathematic Problem Solving Ability Tests, and Self-efficacy Questionnaires.

Furthermore, it can also be concluded that the learning materials uses Problem-Based Learning with the Karo Cultural Context is a learning device that includes the steps of Problem-Based Learning, where the initial problem presented is in the form of contextual problems related to various Karo cultural contexts.

\section{METHOD}

This research was development research (design research). This study used a model of development of Thiagarajan et al. (1974) which is also often referred to as 4-D, includes 4 stages namely define, design, develop and disseminate.

The research was conducted at SMP Negeri 2 Sibolangit, which is one of the junior high schools in Deli Serdang, North Sumatera, Indonesia. Subjects in this study were students of class VII-1 and VII-2 of SMP Negeri 2 Sibolangit in the academic year 2018/2019 which amounted to 32 students. The object in this study is a learning materials developed through a problem based learning with Karo culture context (PBL-KCC) on quadrilateral topic, i.e. lesson plans, student books, student activity sheet, mathematic problem solving ability test, and student self-efficacy questionnaire.

The instruments used in this study were tests and questionnaires. Tests are used to measure mathematical problem solving ability and questionnaires are used to capture responses. Next, to see the effectiveness of the learning materials, which is seen from: (1) Classical learning completeness of students at least $85 \%$ of students who get a mathematical problem solving ability test have obtained a minimum score of 70; (2) Achievement of learning objectives for each item in the test of mathematical problem solving ability of at least 75\%; (3) At least $80 \%$ of students respond positively to the components of the learning materials developed; and (4) The learning time used does not exceed the usual learning time (Hasratuddin, 2018).

To analyze the improvement of students' mathematical problem solving ability, data were obtained from the results of students' pre-test and post-test. Increasing students' mathematical problem solving ability can be obtained from normalized gain index data Hake (1999), as follows:

$$
N-\text { gain }=\frac{\text { posttest value }- \text { pretest value }}{\text { ideal value }- \text { pretest value }}
$$

with the normalized gain index criteria (g) shown in Table 1. 
Table 1. The Normalized Gain Score Criteria

\begin{tabular}{cc}
\hline Gain score & Category \\
\hline $\mathrm{g}>0.7$ & High \\
\hline $0.3<\mathrm{g} \leq 0.7$ & Medium \\
\hline $\mathrm{g} \leq 0.3$ & Low \\
\hline
\end{tabular}

Table 2. Self-efficacy Belief Level

\begin{tabular}{cccc}
\hline \multirow{2}{*}{ Number } & \multicolumn{2}{c}{ Conversion Value } & \multirow{2}{*}{ Category } \\
\cline { 2 - 4 } & Score & Value & Very good \\
\hline 1 & $76-100$ & A & Good \\
\hline 2 & $51-75$ & B & Good enough \\
\hline 3 & $26-50$ & C & Not good \\
\hline 4 & $0-25$ & D &
\end{tabular}

The achievement used in the student's self-efficacy questionnaire was taken based on the Likert scale. To determine student answer scores, researchers applied scoring guidelines for each statement, namely the score for each statement was 1 (strongly disagree), 2 (disagree), 3 (agree), and 4 (strongly agree). Suwandi stated that to determine the range of self-efficacy assessments students used the following criteria shown in Table 2 (Aufa et al., 2016).

\section{RESULT}

\section{The Description of Learning Materials Development Stage}

In this development research, learning materials based on problem based learning with Karo Culture context (PBL-KCC) had met the quality of effective learning materials in trial II. The final draft has been obtained in trial II. The results of the development learning materials using the Thiagarajan 4-D model are described as following.

\section{Stage 1-Define}

Based on the observations of learning materials in SMP Negeri 2 Sibolangit found some weaknesses in the learning materials used by teacher, because the teacher has not developed lesson plan according to student characteristics, subject matter in the book used by teacher and students does not present problem not routines sucha as contextual problem related, and teacher do not use student worksheet as a sopport for learning activities. Futhermore, in the learning process the teacher still uses a conventional education, and the teacher is also not accustomed to giving confidence to students trough motivational words so that students have selfefficacy in solving problem given.

\section{Stage 2-Design}

At this stage produced an initial draft of the lesson plans for 5 meetings, student book, student worksheet, mathematic problem solving ability test, and students' self-efficacy questionnaire. All result at this design stage are called draft I.

\section{Stage 3-Develop}

At this stage, draft I that have been revised based on experts is tested on the outside class of research subject. The aim is to see the weaknesses in draft I so that it can be revised and refined the learning materials developed. The results of expert validation in the form of assessment of content validity which shows that all learning materials meet valid criteria, with a total average value of validation lesson plans is 4.38 , student book is 4.43, and student worksheet is 4.39. All mathematic problem solving ability test items and questionnaires self-efficacy student meet valid and reliable criteria. Instrument reliability is used to determine the test result. After calculation, the reliability of the mathematical problem solving ability test was 0.751 (high category) and the questionnaire self-efficacy was 0.891 (very high category).

After the learning materials developed have met the criteria for validity, then learning materials in the form draft II were tested in the research subject and place, that is SMP Negeri 2 Sibolangit, here in after refered to as trial I. Based on the result of trial I data analysis, it was found that the developing learning materials did not meet all effective criteria, so that improvements were made to produce learning materials 
that meet all the effective criteria set. Revisions were made based on the findings of the leraning materials weaknesses in the trial I, namely for lesson plans related to the allocation of learning time, as well as on student book and worksheet related to the material being taught. After the revision is complete, trial II is conducted to determine the effectiveness of the learning materials, as well as the improvement of mathematical problem solving ability and the attainment of self-efficacy student.

\section{Stage 4-Disseminate}

The development of learning materials reaches the final stage if it has obtained positive values from experts and through development tests. The learning materials are then packaged, distributed and determined for a wider scale. But in this study the disseminate stage was not carried out, so the fourth stage was not explained.

\section{Result of Trial I}

Based on the results of trial I data analysis, it was found that the learning materials developed were not effective, because there were still some indicators of effectiveness that had not been achieved. The results of classical completeness in mathematical problem solving ability of students in the trial I, namely in the pretest was $40.63 \%$ while the posttest was $68.75 \%$. This states that students have not meet the value of classical completeness. Furthermore, for the criteria achieving the learning objectives in the trial I have not yet reached each item.

The indicators of effectiveness that have been fulfilled in the trial I are the attainment of learning time, namely the learning time used is the same as ordinary learning time, besides that it is the response of students, namely students respond positively to learning materials based on realistic mathematics education approach with the average percentage of the total positive responses of students in the trial I was $89.78 \%$.

Improvement of students' mathematic problem solving ability in the trial I was seen through N-gain from the results pretest and posttest of mathematic problem solving ability in the trial I. From the data obtained by students who received score $\mathrm{N}$-gain in the range of $\mathrm{g}>0.7$ or experienced an increase in mathematical problem solving ability with the category "High" as many as 1 student, students who experienced an increase in mathematical problem solving ability with the category "Medium" or got a score N-gain of $0.3<$ g $\leq 0.7$ as many as 12 students and students who experienced an increase in mathematical problem solving abilitiy with the category "Low" or got a score $\mathrm{N}$ - gain of $\mathrm{g} \leq 0.3$ as many as 19 students. While the average N-gain in the trial I obtained 0.3 in the medium category.

Based on the data obtained on the attainment of self-efficacy of students in the trial I most dominating is good category, which indicated that students in the trial I has good self-efficacy.

\section{Result of Trial II}

Based on the results of the trial II data analysis, it was found that the learning materials developed have been effective based on indicators of the effectiveness of the learning materials that have been achieved. The results of classical completeness in mathematical problem solving ability of students in the trial II, namely in the pretest was $62.5 \%$ while the posttest was $87,5 \%$. This states that students have meet the value of classical completeness. Furthermore, for the criteria achieving the learning objectives in the trial II, it was achieved for each item about mathematical problem solving ability.

Likewise, the learning time used is in accordance with the criteria for achieving learning time. Then the average percentage of the total positive responses of students in the trial II was $91,75 \%$, so it can be concluded that students' responses to the components and learning activities was very positive.

Improvement of students' mathematical problem solving ability from the data obtained in the trial II students who received score $\mathrm{N}$-gain in the range of $\mathrm{g}>0.7$ or experienced an increase in mathematical problem solving ability with the category "High" as many as 1 student, there were 21 students experienced an increase in mathematic problems solving ability with the category "Medium" or got a score N-gain in the range $0.3<\mathrm{g}$ $\leq 0.7$ and 10 students experience an increase in mathematical problem solving ability in the category "Low" or got a score $\mathrm{N}$-gain of $\mathrm{g} \leq 0.3$. The average gain in the trial II obtained 0.46 in the medium category.

Based on the data obtained on the achievement of self-efficacy students in the trial II most dominating is good and very good categories, which indicated that students in the trial II has a good self-efficacy. 


\section{DISCUSSION}

Based on the results of posttest analysis of trial I and trial II, it was found that students' mathematic problem solving abilities met classical completeness criteria because the material and problems in the student book and activity sheet were developed according to the characteristics and environment of students, so students could use their previous experiences and utilizing knowledge from their daily environment to solve a mathematic problem that makes the learning process more meaningful. This is in accordance with Ausubel's learning theory which states that meaningful learning is a process of linking new information or material with concepts that already exist in one's cognitive structure (Trianto, 2011). Cognitive structures are facts, concepts, and generalizations that students have learned and remembered. This means that meaningful learning occurs when students try to connect information or new material in the structure of knowledge to solve problems they face.

The application of problem-based learning, students will be actively involved in the problem solving process. Students analyze and evaluate their own thought processes and draw conclusions from knowledge that has been found with guidance and guidance from the teacher or friend in the form of questions that lead. This is reinforced by Vygotsky's view that is problem-based learning is an attempt to associate new information with cognitive structures that have been possessed through learning activities in social interactions (Rusman, 2012). Furthermore, Vygotsky adds that social interaction with other people both teachers and peers can refer to constructing new ideas and increasing students' intellectual development (Arends, 2008). Student learning completeness is also influenced by learning models used in problem-based learning processes that make students interested in learning and actively involved in the learning process (Amalia, et al., 2017).

The achievement of learning objectives by using the PBL-KCC learning materials meets the effectiveness criteria. This is because the application of PBL-KCC materials problems raised from the daily lives of children are more easily understood by children, because they are real, affordable by imagination, and can be imagined, making it easier for him to find possible solutions using mathematical problem solving abilities he has. supported by Yew \& Goh's statement (2016) which stated that PBL is a pedagogical approach that enables students to learn while engaging actively with meaningful problems. Students are given the opportunities to solve problems in collaborative settings, create mental models for learning, and form self-directed learning habits through practice and reflection. This is also supported by the research of Rokhmawati et al. (2016) who said that implementation of PBL models can improve students' problem solving skills. The students can assess their own ability as better problem solvers because in the PBL model, the students have a solution and they will also be dealing with problems, because they are faced with everyday problems. Another study by Argaw et al. (2017) states that the result of this study shows that PBL could be more effective on the problem solving skills than the conventional teaching method. Thus it can be concluded that the achievement of these learning objectives shows that the use of learning tools developed meets the effectiveness criteria.

Based on the results of analysis of data from the results of trial I and trial II, it was found that the percentage of the average response of students in each trial was positive. This means that students provide a positive response to the components of the PBL-KCC learning materials. Students' responses given at each trial have reached the predetermined criteria category, namely $\geq 80 \%$. This shows that the PBL-KCC has met the effective criteria in terms of student responses. A teacher must prepare a mature and accurate learning planning process because with learning planning the teacher will be able to predict how much success will be achieved. This is reinforced by the results of research by Sinaga (2007) which shows that students respond positively to problem-based learning devices based on Batak culture. Based on the explanation of the results of the research and supporting research, it can be concluded that the components of the problem-based learning device developed contribute positively to the students' responses to learning. This is also supported by the results of research by Phungsuk et al. (2017) which stated that the results showed that problem-based learning enhanced learning skills and problem-solving skills among students. Student feedback toward the model is positive, as it follows their interests and used problem solving to stimulate learning. Based on the description above, it can be concluded that the components of the PBL-KCC learning materials developed contribute positively to students' responses to learning.

Based on the results of the improvement in students' mathematic problem solving ability in the trial I and trial II, it showed that there was an increase in students' mathematic problem solving ability from pretest to postest. In trial I, the increase was $28.13 \%$ and in trial II was $25 \%$. Meanwhile, the result increase of posttest trial I and trial II was $18.75 \%$. This shows an increase in students' mathematic problem solving ability after 
using PBM-KCC learning materials. Improvement of students' mathematic problem solving ability due to the learning process using PBL-KCC learning materials begin with contextual problems, so students can use their previous experience in understanding and solving mathematical problems. This is in line with Ausubel's theory that meaningful learning is a process of relating new information to relevant concepts contained in one's cognitive structure (Trianto, 2011). In meaningful learning the learning process starts with contextual problems and information construction processes occur. discussion conducted by students is a bridge of mutual help between students in understanding contextual problems.

Regarding the problem based learning model and students' mathematic problem solving abilities, research conducted by Amalia et al. (2017) stated that the results showed that average value students who were taught by PBL were higher than students who were taught by using conventional models. Research results of Ammamiarihta et al. (2017) stated that learning devices oriented Problem Based Learning are valid both in terms of content and construct, practical to use, and effective and students' mathematical problem solving ability increased. Related to the PBM model that has cultural context, the results of Lubis et al. (2017) stated that he results obtained from the learning tool through a learning-based model of learning based on Batak culture developed have valid, practical and effective criteria and there is an improvement of problem solving skills. Based on the description and results of previous studies above, it is shown that learning with PBM models is significantly better in improving students' mathematical problem solving abilities. So that it can be concluded that the PBL-KCC device has a positive impact on improving students' mathematic problem solving ability.

Based on the results of the questionnaire self-efficacy data analysis of students in the first trial and trial II showed that there was an increase in student self-efficacy. This shows that the use of PBL-KCC learning mterials developed has an impact on increasing student self-efficacy. The success of students in solving these problems will increase students' self-efficacy beliefs (Schunk \& Pajares, 2001). Students' vicarious experience in mathematics learning can be improved by giving students the opportunity to see their friends succeed in solving problems or the teacher explains how other students solve problems (Bonne \& Lawes, 2016). The PBLKCC learning materials accommodates the vicarious experience through presentation of the results of problem solving and student discovery. Future studies related to self-efficacy and students 'mathematical problem solving conducted by Rokhmawati, et al. (2016) stated, that the study results show that the implementation of PBL models can improve the students' problem solving skill and self-efficacy. The development of PBK-KBK learning materials that use this local culture get results that are in accordance with previous development research that uses local culture. As the results of device development research obtained by Azwar, et al. (2017) which stated that the development of learning tools based on the Aceh Cultural context is effective in increasing student self-efficacy. Based on the description and results of previous studies above, it shows that the use of PBL-KCC learning devices can improve student self-efficacy.

\section{CONCLUSION}

Based on the results of analysis and discussion in this study, it can be concluded that learning materials based on Problem Based Learning with Karo Culture context (PBL-KCC) have met the effectiveness criteria and mathematic problem solving ability and student self-efficacy have increased. This research shows that learning materials based PBL-KCC are important things to consider in an effort to maximize student mathematics learning achievement. Thus, it is expected that mathematics teachers seek mathematic learning using learning materials based on PBL-KCC.

\section{Disclosure statement}

No potential conflict of interest was reported by the authors.

\section{Notes on contributors}

Siska Apulina Peranginangin - State University of Medan, Medan, Indonesia.

Sahat Saragih - State University of Medan, Medan, Indonesia.

Pargaulan Siagian - State University of Medan, Medan, Indonesia. 


\section{REFERENCES}

Amalia, E., Surya, E., \& Syahputra, E. (2017). The Effectiveness of Using Problem Based Learning (PBL) in Mathematics Problem Solving Ability for Junior High School Students. IJARIIE-ISSN(O)-2395-4396, $3(2)$.

Ammamiarihta, Syahputra, E., \& Surya, E. (2017). Development of Learning Devices Oriented Problem Based Learning to Increase Student's Combinatorial Thinking in Mathematical Problem Solving Ability. Advances in Social Science, Education and Humanities Research, 104. https://doi.org/10.2991/aisteel17.2017 .71

Arends, R. I. (2008). Learning to Teach. Buku Dua. Edisi Ketujuh.Yogyakarta: Pustaka Pelajar.

Argaw, A., Haile, B., Ayalew, B., \& Kuma, S. (2017). The Effect of Problem Based Learning (PBL) Instruction on Students' Motivation and Problem Solving Skills of Physics. EURASIA Journal of Mathematics Science and Technology Education. https://doi.org/10.12973/eurasia.2017.00647a

Arikunto, S. (2010). Prosedur Penelitian: Suatu Pendekatan Praktik. Yogyakarta: PT. Rineka Cipta.

Aufa, M., Saragih, S., \& Minarni, A. 2016. Development of Learning Devices through Problem Based Learning Model Based on Context of Aceh Cultural to Improve Mathematical Communication Skills and Social Skills of SMPN 1 Muara Batu Students. Journal of Education and Practice, 7(24).

Aydogdu. (2014). A Research On Geometry Problem Solving Strategies Used By Elementary Mathematics Teacher Candidates. Journal of Educational and Instructional Studies in The World, 4(1), Article:07.

Azwar, Surya, E., \& Saragih, S. (2017). Development of Learning Devices Based on Contextual Teaching and Learning Model Based on the Context of Aceh Cultural to Improve Mathematical Representation and Self-efficacy Ability of SMAN 1 Peureulak Students. Journal of Education and Practice, 8(27), 186195.

Bandura, A. (1994). Self-efficacy. In V. S. Ramachaudran (Ed.), Encyclopedia of humanbehavior (4, 71-81). New York: Academic Press. (Reprinted in H. Friedman (Ed.), Encyclopedia of Mental Health. San Diego: Academic Press, 1998).

Bonne, L., \& Lawes, E. (2016). Assessing Students Maths Self-Efficacy and Achievement. Assessment News. 2, 60-63. https://doi.org/10.18296/set.0047

Charles, R., Lester, F., \& O’Daffer, P. (1987). How to Evaluate Progress in Problem-Solving. Reston, VA: National Council of Teachers of Mathematics.

D’Entremont, Y. (2015). Linking Mathematics, Culture and Community. Procedia - Social and Behavioral Sciences, 174, 2818-2824. https://doi.org/10.1016/j.sbspro.2015.01.973

Dumciuviene, D. (2015). The Impact Of Education Policy To Country Economic Development. Procedia - Social and Behavioral Sciences, 191, 2427-2436. https://doi.org/10.1016/j.sbspro.2015.04.302

Fitriani. (2014). Pengembangan Perangkat Pembelajaran Melalui Model Pembelajaran Kooperatif Tipe Jigsaw Untuk Meningkatkan Kemampuan Komunikasi Matematik Siswa di SMP Kelas VIII. Jurnal Pendidikan Matematika PARADIKMA, (Online), 7(2).

Furinghetti, F., \& Morselli, F. (2009). Every Unsuccessful Problem Solver Is Unsuccessful in His or Her Own Way: Affective and Cognitive Factors in Proving. Educ Stud Math, 70, 71-90. https://doi.org/10.1007/s10649-008-9134-4

Gafur, M., \& dan Sudia, M. (2015). Meningkatkan Kemampuan Memecahkan Masalah Open-Ended Siswa Kelas VII-2 SMPN 3 Kulisusu Melalui Pendekatan Pengajuan Masalah Pada Pokok Bahasan Segi Empat. Jurnal Penelitian Pendidikan Matematika, 3(1).

Hake, R. R. (1999). Analizing Change/Gain Scores. Woodland Hills: Dept. Of Physics, Indiana University.

Hasratuddin. (2018). Mengapa Harus Belajar Matematika?. Medan: Penerbit Perdana Publishing.

Lesh, R., \& Zawojewski, J. S. (2007) Problem Solving and Modeling. In: Lester, F., Ed., Second Handbook of Research on Mathematics Teaching and Learning, Information Age Publishing. Greenwich CT, 763802.

Lubis, A., Harahap, M. B., \& Derlina. (2017). Development of Problem Based Learning Model Based on Batak Culture to Increase Problem Solving Skills and Students' Adversity Quotient. IOSR Journal of Research \& Method in Education (IOSR-JRME) 7(6), 22-28.

Lunenburg, F. (2011). Self-Efficacy in the Workplace: Implications for Motivation and Performance. International Journal of Management, Business, and Administration, 14(1). 
Manurung, B. (2015). Peningkatan Kemampuan Pemecahan Masalah dan Self-efficacy Matematis Siswa SMP Paulian 1 Medan Melalui Pembelajaran Berbasis Masalah. Tesis PPs UNIMED.

NCTM. (2000). Principles and Standards for School Mathematics. Reston, VA: National Council of Teachers of Mathematics (NCTM).

Olayinka, A. R. B. (2016). Effects of Instructional Materials on Secondary Schools Students' Academic Achievement in Social Studies in Ekiti State, Nigeria. World Journal of Education, 6(1), 32-39. https://doi.org/10.5430/wje.v6n1p32

Ozturk, T., \& Guven, B. (2016). Evaluating Students' Beliefs in Problem Solving Process: A Case Study.. Eurasia Journal of Mathematics, Science \& Technology Education, 12(2), 411-429.

Pehkonen, E. (2012). Problem Solving in Mathematics Education in Finland. WG2, Topic \#8: Different conceptions of the mathematical knowledge needed for teaching and how it can be acquired, and its relation to pedagogical knowledge.

Peranginangin, S. A., \& Surya, E. (2017). An Analysis of Students' Mathematics Problem Solving Ability in VII Grade at SMP Negeri 4 Pancurbatu. International Journal of Sciences: Basic and Applied Research (IJSBAR).

Phungsuk, R., Viriyavejakul, C., \& Ratanaolarn, T. 2017. Development of A Problem-Based Learning Model Via A Virtual Learning Environment. Kasetsart Journal of Social Sciences, 38. https://doi.org/10.1016/j.kjss.2017.01.001

Rokhmawati, Diah, J., Djatmika, E., \& Wardana, L. (2016). Implementation of Problem Based Learning Model to Improve Students' Problem Solving Skill and Self-Efficacy (A Study on IX Class Students of SmpMuhammadiyah). IOSR Journal of Research \& Method in Education (IOSR-JRME), 6(3), 51-55. Retrieved from www.iosrjournals.org

Rusman. (2012). Model-Model pembelajaran Mengembangkan Profesionalisme Guru Edisi Dua. Jakarta: PT Raja Grafindo Persada.

Sapta, A., Hamid, A., \& Syahputra, E. (2018) Assistance of Parents in the Learning at Home. IOP Conf. Series: Journal of Physics: Conf. Series 114 (2018)012020. WMA-Matchcomtech 2018.

Saragih, S., Napitupulu, E., \& Fauzi, M. (2017). Developing Learning Model Based on Local Culture and Instrument for Mathematical Higher Order Thinking Ability. International Education Studies, 10(6). https://doi.org/10.5539/ies.v10n6p114

Sartawi, A. (2012). Predicting Mathematics Achievement by Motivation and Self -Efficacy Across Gender and Achievement Levels. Interdisciplinary Journal of Teaching and Learning, 2(2).

Schunk, D. H., \& Pajares, F. (2001). The Development of Academic Self-Efficacy. Wigfield \& J. Eccles (Eds.) Development of Achievement motivation. San Diego: Academic Press. San Diego: Academic Press.

Sinaga, B. (2007). Pengembangan Model Pembelajaran Matematika Berdasarkan Masalah Berbasis Budaya Batak (PBMB3). Disertasi. Tidak dipublikasikan. Surabaya: PPs. Unesa.

Tambychik, T., Subahan, M., \& Meerah, M. (2010). Students' Difficulties in Mathematics Problem-Solving: What Do They Say?. International Conference on Mathematics Education Research 2010 (ICMER 2010 Procedia Social and Behavioral Sciences, 8, 142-151. https://doi.org/10.1016/j.sbspro.2010.12.020

Thiagarajan, S., Semmel, D. S., \& Semmel, M. I. (1974). Instructional Development for Training Teachers of Exceptional Children. A Sourcebook Indiana: Indiana University.

Trianto. (2011). Mendesain Model Pembelajaran Inovatif-Progresif. Konsep Landasan, dan Implementasinya pada Kurikulum Tingkat Satuan Pendidikan (KTSP). Jakarta: Kencana Prenada Media Group.

Trianto. (2013). Model Pembelajaran Terpadu dalam Teori dan Praktek. Jakarta: Prestasi Pustaka.

Vettleson. (2010). Problem Solving Based Instruction in The High School Mathematics Classroom. Bemidji: School of Graduate Studies.

Vygotsky, L. S. (1978). Mind in Society: The Development of the Higher Psychological Processes. Cambridge, MA: The Harvard University Press.

Yew, E. H. J., \& Goh, K. (2016). Problem-Based Learning: An Overview of Its Process and Impact on Learning. Health Professions Education, 2, 75-79. https://doi.org/10.1016/j.hpe.2016.01.004 